Mitteilungen der Österreichischen Geographischen Gesellschaft,

158. Jg. (Jahresband), Wien 2016, S. 167-192

\title{
The Long-Run Interregional Distribution of Human Capital in Austria: What Role for KNowledge InTEnsity of Production? ${ }^{1}$
}

\author{
Sascha SARDADVAR and Assma HAJJ, both Vienna [Wien]*
}

with 4 figures and 4 tables in the text

\section{CONTENTS}

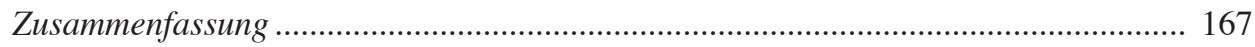

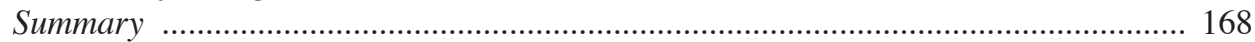

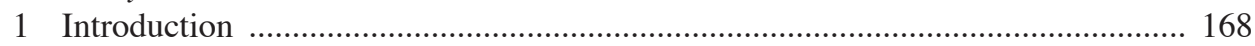

2 Regional human capital accumulation ........................................................... 170

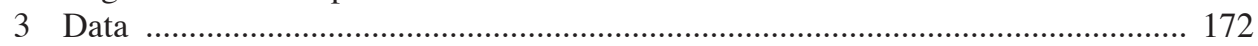

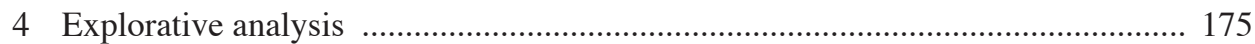

5 Cross-sectional regressions ..................................................................... 182

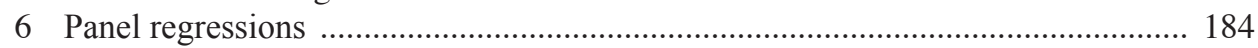

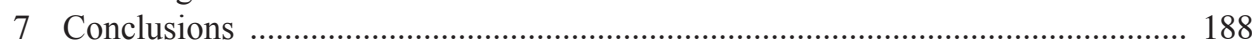

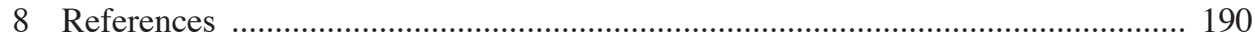

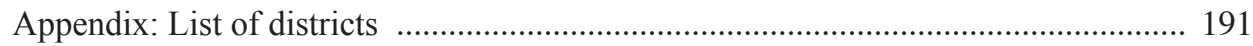

\section{Zusammenfassung}

Die langfristige interregionale Verteilung des Humankapitals in Österreich: Welche Rolle spielt die Wissensintensität der Produktion?

Ziel des vorliegenden Artikels ist es, die Determinanten regionaler Humankapitalausstattungen innerhalb Österreichs für den Beobachtungszeitraum 1971-2011 zu identifizieren. Im Vordergrund stehen die Fragen, ob erstens die räumliche Konzentration des

1) The study was funded by the Vienna University of Economics and Business and conducted at its Institute for Economic Geography and GIScience. The authors would like to thank the reviewers for their helpful comments.

* Priv.-Doz. Mag. Dr. Sascha Sardadvar, WPZ Research, Mariahilfer Straße 115/16, A-1060 Wien; email: sascha.sardadvar@wpz-research.com; Assma HAJJI, MSc, BA, Research Institute for Economics of Aging, Vienna University of Economics and Business (WU Vienna), Welthandelsplatz 1/D4, A-1020 Wien; email: assma.hajji@wu.ac.at 
Humankapitals wie in anderen Ländern im Zeitverlauf zunimmt und zweitens, inwieweit die Wissensintensität der laufenden Produktion die gegenwärtige und zukünftige Humankapitalausstattung bestimmt. Im vorliegenden Artikel werden explorative und explanatorische Analysen verbunden, wobei letztere Querschnitts- und Paneldaten-Regressionen umfassen. Die abhängige Variable misst die durchschnittliche Schulbesuchsdauer der regional Werktätigen, der Beobachtungsraum besteht aus den 99 österreichischen Politischen Bezirken. Die Schätzungen zeigen, dass die regionalen Humankapitalausstattungen bis 1991 konvergierten und seither divergieren. Es zeigt sich außerdem ein negativer Einfluss der industriellen Produktion mit niedriger und mittel-niedriger Technologie auf das Wachstum der regionalen Humankapitalausstattungen, aber kaum Einfluss hoher Technologieniveaus. Im Unterschied dazu wirkt sich die Präsenz wissensintensiver Dienstleistungen positiv aus.

Schlagwörter: Humankapital, Wissensintensität, räumliche Disparitäten, Österreich

\section{Summary}

The objective of this paper is to identify the determinants of regional human capital endowments within Austria for the observation period 1971-2011. The two key questions are (i) whether, as observed in other countries, the spatial concentration of human capital increases over time and (ii) to what extent the knowledge intensity of current production affects current and future human capital endowments. The present paper combines an explorative with an explanatory study, where the latter consists of cross-sectional and panel regressions. The dependent variable equals average schooling years of the employed persons in a region, the observation area consists of Austria's 99 districts. The estimations show that human capital endowments have converged across regions until 1991 and diverged again since then. Furthermore, the regression results display a negative impact of low and medium-low, but almost no impact of high and medium-high technology manufacturing industries on human capital growth. In contrast, the impact of knowledge-intensive services is positive.

Keywords: human capital, knowledge intensity, spatial inequality, Austria

\section{Introduction}

As pointed out by FagGian \& Franklin (2014, pp. 377), one of the few things that economists and other social scientists agree upon is the importance of human capital for both individuals and society. The specific role human capital plays for modern economies to thrive has been pioneered by LuCAs (1988) and Mankiw et al. (1992). At least since Marshall (1890) released his thoughts on economies of localisation, the interplay of regional availability of skills and location of industries is one of the key issues of economic geography. 
The spatial availability of human capital has gained special attention over the past quarter century in studies that deal with regional development. Models of new economic geography (in particular KRUGMAN 1991) and neoclassical growth theory (for a discussion see SARDADVAR 2016) show how initial endowments and subsequent migration of human capital determine regional development. Human capital endowments depend on the industrial mix of a region, where high-productivity activities are those with high percentages of skilled workers (PRAGER \& THISSE 2012, pp. 33). From this it follows that future human capital accumulation and hence the development of a region depends on its current human capital endowment, which is in turn shaped by the current economic structure.

The key question, therefore, relates to the links of employment and schooling to local aspects. Some authors hypothesise that human capital levels across cities and regions are diverging (SHAPIRO 2006; FloRIDA et al. 2008), but empirical evidence that confirms this hypothesis is largely based on regions and cities in the United States (in particular BERRY \& Glaeser 2005; GanONG \& ShoAg 2012). In contrast, studies for European countries (SÜDEKUM 2008; RATTS $\varnothing$ \& STOKKe 2013) have found convergence of human capital endowments. In a study based on Austrian districts, SARDADVAR \& REINER (2015) also find strong convergence of human capital endowments which has, however, decelerated since the 1990s. It should be mentioned that these studies in most instances equalise human capital with the share of college and university graduates which is discounting a large part of human capital as it, by definition, captures all types of skills.

As will be shown in the present paper, over the past decades educational levels of the Austrian population have increased considerably. Nevertheless, with respect to the correlation of human capital with economic productivity, Austria is almost an outlier: Within the 28 member states of the EU, as of 2013 Austria ranks fourth in terms of GDP per capita, but only $21^{\text {st }}$ with respect to the share of population with tertiary education. ${ }^{2}$ At the same time, those with tertiary education concentrate in the large cities. While the spatial distribution of the tertiary educated shows only small variations over young and old population cohorts, those with only compulsory schooling have decreased relatively in rural areas but increased in the large cities over the past decades (SCHWABE 2006). This observation underlines that an equalisation of human capital with tertiary education may lead to biased results.

The aim of this paper is to identify the relevance of technology and economic structure regarding regional human capital levels in Austria. By using a data set on the district level that goes back to 1971, we are able to analyse long-run effects. Special attention is paid to the roles of knowledge intensity of the manufacturing and service sectors, in addition to other economic variables. Cross-sectional and panel regressions are run in order to estimate the impacts of the variables on current schooling levels and their changes over time, respectively. The results reveal that the impacts on current levels and growth differ remarkably.

The present paper contributes to the literature in two ways. Firstly, it examines the interplay between the technological structures of regional economies and their current as

2) Data source: Eurostat, downloaded on 8-September-2015; tertiary education refers to ISCED levels 5-8, working age population to $25-64$ years old. 
well as future human capital endowments. Secondly, it provides evidence whether human capital levels in Austria are self-reinforcing or converging.

The paper is organised as follows. Section 2 presents the theoretical background. Section 3 introduces the reader to the educational system in Austria and presents the data. An explorative analysis can be found in Section 4, followed by explanatory analyses based on cross-sectional and panel regression in Sections 5 and 6, respectively. Finally, Section 7 concludes.

\section{Regional human capital accumulation}

Over the past years, numerous studies have been released that deal with the interregional distribution of human capital. In this context, the "creative class" as defined by FLORIDA (2002) and "smart cities" as defined by SHAPIRO (2006) have received considerable attention. The two concepts are related as they deal with the relationship between human capital endowments and regional development. The basic conclusion proclaims that a region or city that is able to attract human capital will thrive, firstly as a matter of higher productivity of these workers who supply human capital, and secondly because they increase a region's attractiveness for new investments, therefore leading to employment growth. Other welcomed effects such as increased quality of life (SHAPIRO 2006) and high technology industry location (FLORIDA 2002) are also present.

There exist, however, several limits to the creative class and smart cities concepts, especially in European and Austrian contexts. Firstly, equalising human capital with college and university graduates not only abstracts from the horizontal and vertical differences with respect to degrees but also completely ignores the skills of the larger part of the labour force. Secondly and to some extent related, focussing on the interplay with high technology industries ignores the larger part of production. A third problem relates to the inconsistency of applied levels of aggregation regarding sectors and regions (see MAMELI et al. 2014, for a discussion), making comparisons of empirical results difficult.

A potential further reason why studies conducted for various countries display various and seemingly contradictory results relates to the fact that countries are in fact different to each other. The Varieties of Capitalism Paradigm as developed by HaLl \& Soskice (2001) distinguishes liberal market economies (LMEs) such as the United Kingdom and the United States from coordinated market economies (CMEs) such as Austria and Germany. Of a number of criteria that distinguish these types, two are of particular relevance in the context of the present paper. Firstly, the comparative advantage of LMEs lies in radical innovation, whereas CMEs have advantages regarding incremental innovation (ALLEN 2006). From this it follows that the high technology sector is of greater importance in LMEs. As the recent empirical records show, the share of manufacturing in total production tends to be higher in CMEs than in LMEs, with the latter being characterised by deindustrialisation in the years before the current crisis commenced (REINER 2012).

Secondly, skill-acquiring differs between CMEs and LMEs, where in the former the training systems are heavily oriented around firm-based training, and the skill sets they 
confer are said on average to be less general (Soskice 1994, cited in CULPEPPER 2007). In other words, a CME such as Austria is expected to develop a high degree of vocational education leading to industry-specific skills and long-term employment. By comparing the Austrian to the Swiss system, CULPEPPER (2007) points out that it is especially the high share of cost-conscious small firms in Austria that are interested in having access to cheap labour with specific skills.

On the other hand, the empirical literature showing that investment in education leads to better job opportunities is overwhelming (EDZES et al. 2015). Furthermore, to improve human capital and to invest in research and development (R\&D) are considered as main goals of the EU's Lisbon and Europe 2020 Strategies, therefore reflecting theoretical findings regarding the importance of human capital. The RePUblic of Austria (2011) has expressed its goal to become an "innovation leader" by increasing the ratio of R\&D spending to GDP to $3.76 \%$ until 2020 . Among the means to achieve this goal are further expenditures in education in order to increase the national human capital stock (ibid., pp. 16).

Considering intra-country human capital development, regions and cities with more higher education activity, in particular universities and colleges, can increase the local supply of human capital (ABEL \& DeITz 2011). In addition, the presence of colleges and universities may increase the regional human capital stock beyond its direct supply and demand effects, as the presence of universities tilts the structure of local labour markets towards occupations that are more human capital intensive (ABREU et al. 2015). It comes as no surprise that Austria's ambitious goals regarding innovativeness are accompanied by an increase in the number of colleges and universities from 21 in 1971 to 69 in 2011 . $^{3}$ Furthermore, with respect to non-tertiary education, the spatial distribution of human capital in Austria is characterised by the presence of corresponding schools (SCHWABE 2006). Therefore, it is likely that current human capital endowments are correlated with future endowments.

Agglomeration effects constitute a further aspect that is likely to affect regional human capital endowments, where physical proximity of firms and people in dense urban areas facilitates knowledge flows and lowers the costs of generating new ideas and exchanging information (ABEL et al. 2012). If agglomeration effects are at work, they may increase the attractiveness of a region regarding human capital suppliers. For instance, COMBES et al. (2007) show for France that the most productive workers are located in the densest areas, which leads to the conclusion that workers with better labour market characteristics (i.e., higher human capital) migrate to agglomerations which are already highly endowed with human capital. Another factor that affects the migration of high-skilled workers is geographical location as such, as remote regions with low market access may be less attractive and hence disadvantaged (LóPEZ-RODRíGUEZ et al. 2007).

To conclude the discussion, the present paper focuses on the effects of economic circumstances and developments on human capital regional endowments. Accordingly, the empirical part focuses on rather small administrative entities, where mobility between these entities happens at little cost. Furthermore, the empirical part considers the regional employment instead of residents and hence includes commuters and international migrants.

3) Data source: See Section 3. 
Therefore, the factors that determine regional human capital endowments may be split into four broad categories: Firstly, geographical characteristics such as a region's population density or its location in space; secondly, a region's economic structure as captured by the degree of specialisation or firm sizes; thirdly, the degree of technology that the firms present in a region operate with; fourthly, education opportunities within the region. Since regional human capital endowments are also shaped by internal migration within a country, the general economic situation may be added as a fifth factor.

\section{Data}

In this section, first we briefly review the Austrian education system in order to construct a variable that captures the various types of graduation. After that, we define the corresponding dependent variable as applied in the subsequent analyses. In the final part of this section, we present the explanatory variables that represent the categories as summarised above.

Compulsory schooling comprises a total of nine years including possibly repeated school years. Primary education [Volksschule] starts at the age of six and lasts four years for all children, whereas the secondary school system is differentiated with respect to education purposes and duration. Academic secondary schools [Allgemein Bildende Höhere Schulen, AHS] last for eight years and end with a university entrance exam. Lower secondary schools [Hauptschulen] last for four years and are generally followed by (i) a oneyear pre-vocational school [Polytechnische Lehranstalt], (ii) professional training in the form of an apprenticeship accompanied by a one to four year part-time vocational school [Berufsbildende Pflichtschule, BPS] or (iii) a transfer to a different school type.

At the age of 14, students coming from either school type may also enter a vocational secondary school with a duration of three to five years offering a professional education, some of which end with a university entrance exam [Mittlere Berufsbildende Schulen, BMS, and Höhere Berufsbildende Schulen, BHS]. After taking this exam, students may enrol for studies at universities or universities of applied sciences [Fachhochschulen], or opt for different forms of post-secondary education [Hochschulverwandte Lehranstalten and Akademien], many of which provide professional education for the education, health and social sectors.

The Austrian education system is characterised by a high complexity stemming from a multitude of different school types (academic, vocational and combined forms) as well as a relatively low share of highly-qualified population including university graduates. FASSMANN (2002) argues that while the educational expansion from the 1960s and 1970s led to an increase in graduates at the secondary, post-secondary and tertiary levels, Austria still lags behind at the international level, with the rate of graduates being relatively low compared to other European countries.

Another characteristic feature of the Austrian education system lies in the relative importance of the apprenticeship system. According to FERSTERER et al. (2008), apprenticeship systems (which are also present in other German-speaking countries) are believed to 
offer an easy transition from school to work by combining professional training in firms with part-time school education and can therefore aid in keeping youth unemployment levels relatively low.

\begin{tabular}{|l|c|l|c|}
\hline \multicolumn{1}{|c|}{ School type } & $\begin{array}{c}\text { ISCED 1997 } \\
\text { equivalent }\end{array}$ & \multicolumn{1}{|c|}{ Minimum duration } & $\begin{array}{c}\text { Total } \\
\text { years }\end{array}$ \\
\hline Compulsory school & 2 & 4 yrs primary, 4 yrs secondary, 1 yr pre-vocational & 9 \\
\hline Apprenticeship & $3 \mathrm{~b}$ & $\begin{array}{l}\text { 4 yrs primary, 4 yrs secondary, 1-3 yrs apprentices- } \\
\text { hip / part-time vocational }\end{array}$ & 11 \\
\hline $\begin{array}{l}\text { Vocational secondary } \\
\text { school (BMS) }\end{array}$ & $3 \mathrm{~b}$ & $\begin{array}{l}\text { 4 yrs primary, 4 yrs secondary, 3 yrs vocational } \\
\text { secondary }\end{array}$ & 11 \\
\hline $\begin{array}{l}\text { Academic secondary } \\
\text { school (AHS) }\end{array}$ & $3 \mathrm{a}$ & $\begin{array}{l}\text { 4 yrs primary, 8 years academic secondary, univer- } \\
\text { sity entrance exam }\end{array}$ & 12 \\
\hline $\begin{array}{l}\text { Vocational secondary } \\
\text { school (BHS) }\end{array}$ & 3a/4a & $\begin{array}{l}\text { 4 yrs primary, 4 years (academic) secondary, 5 yrs } \\
\text { vocational secondary, university entrance exam }\end{array}$ & 13 \\
\hline $\begin{array}{l}\text { Post-secondary school } \\
\text { Sniversity, university of } \\
\text { applied science }\end{array}$ & $\begin{array}{l}3 \text { yrs of post-secondary education following a } \\
\text { university entrance exam }\end{array}$ & 15 \\
\hline
\end{tabular}

Tab. 1: Schooling years per education branch

Table 1 displays the Austrian educational attainment categories, their equivalent International Standard Classification of Education (ISCED) categories, the corresponding minimum duration of education and the resulting total number of years. The ISCED equivalents listed are coded according to ISCED 1997 mappings by the United Nations Educational, Scientific and Cultural Organisation (UNESCO). The respective minimum durations were calculated using the minimum number of years needed to complete a certain education category (i.e., only statutory school years were accounted for).

For categories having undergone a structural change associated with a change in duration, current values were used. This applies in particular to university education which was restructured in the course of the Bologna Process as well as to certain types of post-secondary technical and vocational schools [Hochschulverwandte Lehranstalten]. For graduates of universities and universities of applied sciences, five years of schooling were assumed, amounting to a degree at the master's level. Categories containing heterogeneous school forms differing in length were coded using the most common form. This applies to apprenticeships which range from two to four years in duration, with the most common ones being three years (FERSTERER et al. 2008), as well as for the above mentioned post-secondary technical and vocational schools, most of which have a duration of three years and were coded as such. Possible cases of persons who, for some reason, did not complete the current minimum compulsory education of nine years of schooling are included in the first category nonetheless. 
As a next step, we construct a variable for educational attainment at the district level. It is calculated as the average years of schooling for the people employed in a given district $i$ at time $t$ :

$$
S_{i, t}=\sum_{k=1}^{7} h_{i, k, t} d_{k}
$$

with $h$ being the share of the employees having completed a certain education category, and $k$ and $d$ corresponding to the school types and total years as given in Table 1, respectively. From this it follows that:

$$
\sum_{k=1}^{7} h_{i, k, t}=1 \forall i, t
$$

The variable $s$ serves as a measure of average schooling years and as an indicator for human capital, which is why the two terms will be used synonymously in what follows. Although $s$ may not capture all trends in educational structure (e.g. polarisation trends in the large urban areas), its strength lies in capturing developments below the highest educational levels.

The units of observation used in the present paper are the 99 Austrian districts [Politische Bezirke] and statutory cities [Städte mit eigenem Statut] (referred to as "districts" or "regions" henceforth), a list of which can be found in the Appendix. The observation period covers the time span 1971-2011 with data being available for the years 1971, 1981, 1991, 2001 and 2011. Education data were obtained from STATISTIK AUSTRIA, the national statistics institute. Average schooling years were calculated using data on people working in a given district. Commuters are therefore included in the count for the region they are working in, not their residential district. Furthermore, the data includes immigrants and foreigners and therefore controls for effects as induced by international migration.

The explanatory variables represent the five categories as summarised in the previous section: Geographical characteristics, a region's economic structure, the degree of technology, education opportunities and the general economic situation. Geographical characteristics include employee density as calculated from official numbers. In addition, we control for suburbanity and whether a region bordered member states of the Council for Mutual Economic Assistance (Comecon), with the respective classifications given in the list of districts in the Appendix.

Economic structure is captured by the (i) number of employees in small firms, with the latter being defined as one that occupies nine or less employees, the (ii) total number of large firms, with the latter occupying 100 or more employees, and (iii) specialisation as captured by the KRUGMAN index (see MöLler 2012) based on the above-mentioned 60 sectors. Data on firm-size distributions stem from business statistics [Betriebsstättenzählung], the estimation of small firm employees follows SARDADVAR \& REINER (2015).

For the variables pertaining to the degree of technology of the manufacturing sector, industry employment data from the population censuses were used. The data were harmonised so that for each point in time each industry matches the ÖNACE ${ }^{4)} 1995$ classification

4) ÖNACE refers to the Austrian (Ö) version of the Nomenclature générale des activités économiques (NACE) dans les Communautés européennes. 
which corresponds to NACE Rev.1. This classification comprises 60 economic sectors which were then aggregated following EUROSTAT's classification of economic activities according to technological and knowledge intensity which groups manufacturing industries into high, medium-high, medium-low and low technology sectors.

Market service industries are categorised as knowledge-intensive and less knowledgeintensive services (henceforth referred to as KIS and LKIS, respectively) following EUROSTAT's classification, too. The degree of knowledge-intensity in market service industries is based on the threshold of whether more or less than one third of the employees are tertiary educated. ${ }^{5)}$ Note that public services are not included in this categorisation. The sectors of agriculture, fishery, mining, energy and water industries as well as building industries are not included either.

In addition, we consider the number of universities, including universities of applied sciences, as an indicator of education opportunities within the region. The data was collected directly from universities' websites and from information provided by the Ministry of Science, Research and Economy [Bundesministerium für Wissenschaft, Forschung und Wirschaft (BMWFW)]. We counted universities at the district level for all relevant years, where institutions with several sites in the same district are only included once.

Finally, the general economic situation is captured by the unemployment rates and regional productivity levels. The former were taken from population census data collected by the national statistics institute. Note that the dataset does not include employees below reporting threshold [geringfügig Beschäftigte] for any of the years used in the calculations. Regional productivity is measured by gross value added (GVA) per employee. ${ }^{6}$

\section{Explorative analysis}

Educational policy in the 1970 s was geared towards increasing tertiary education participation and did so by reducing entry barriers to higher education, namely by abolishing tuition fees and increasing student funds. According to PeCHAR (2007), the social opening of universities taking place in that period led to a sharp increase in student numbers, especially those from formerly educationally disadvantaged backgrounds.

This can be observed by exploring in the education data, as average years of schooling rose throughout the entire observation period. Growth rates were highest in the early periods of the educational expansion during the 1970s and 1980s and stalled during the 1990s and 2000s. This is also reflected in current cohort-specific education data for the

\footnotetext{
5) It follows that for each point in time all industries' assignments correspond to EUROSTAT's current classification. For details on EuROSTAT's classifications of both manufacturing and service industries see http://ec.europa.eu/eurostat/cache/metadata/Annexes/htec_esms_an2.pdf, accessed 19-October-2015.

6) The data for 1971-1995 were estimated by The Austrian Conference on Spatial Organisation [Österreichische Raumordnungskonferenz (ÖROK)], data for 1995-2011 are available from STATISTIK AUSTRIA at the NUTS-3 level and have been estimated by the authors for the years 2001 and 2011 at the district level by assuming that the growth rate for the NUTS-3 region is identical to each of its districts.
} 


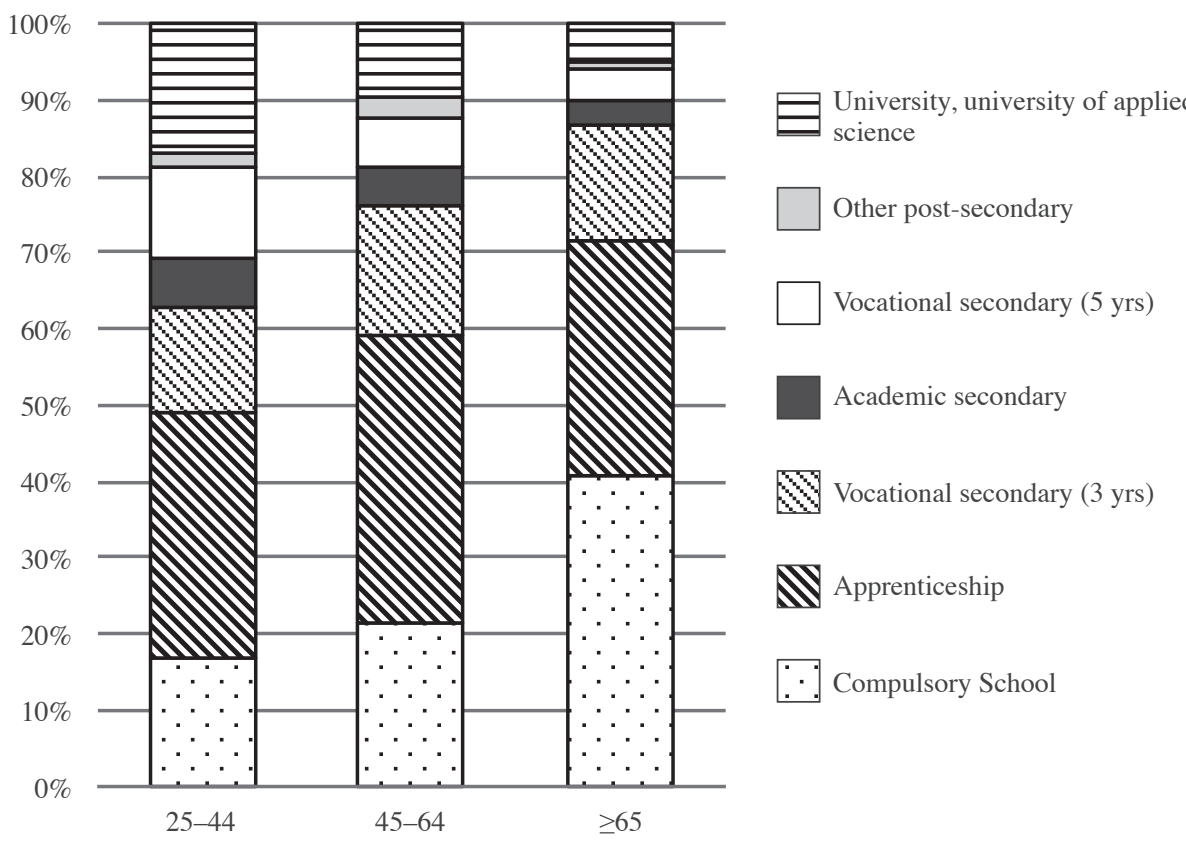

Data source: STATISTIK Austria

Fig. 1: Educational attainment by age cohort in 2013

year 2013, as depicted in Figure 1. The diagram displays a general increase in education in younger cohorts, with the most striking differences being found between the groups $45-64$ and $\geq 65$. The latter was largely not yet affected by the educational expansion, since it can be assumed that persons being 20 years and over in 1970 had either already finished their formal education by then or were in the process of doing so. Accordingly, this cohort shows a relatively high share of persons having only completed primary education, and only 5\% university graduates. The latter number doubles in the 45-64 group, while the share of persons with only primary education is cut by half. The differences between the age groups 25-44 and 45-64 are less remarkable, although a general rise in education is visible especially with respect to the lowest and highest levels. ${ }^{7)}$

The maps of Figures $2 \mathrm{a}$ and $2 \mathrm{~b}$ visualise the spatial distributions of human capital endowments in 1971 and 2011, respectively. In both years, the federal states' capital cities and other urban areas dominate the highest quintiles, including regions which surround Vienna [Wien]. A closer look at Figure 2a reveals that the lowest quintile is dominated by regions which border the Comecon, reflecting their disadvantaged geographical position during the times of economic bloc formation. When comparing 2011 with 1971, the distribution seems to have shifted in favour of Eastern Austria, where in particular the most

\footnotetext{
7) Note that these numbers are also affected by international migration.
} 


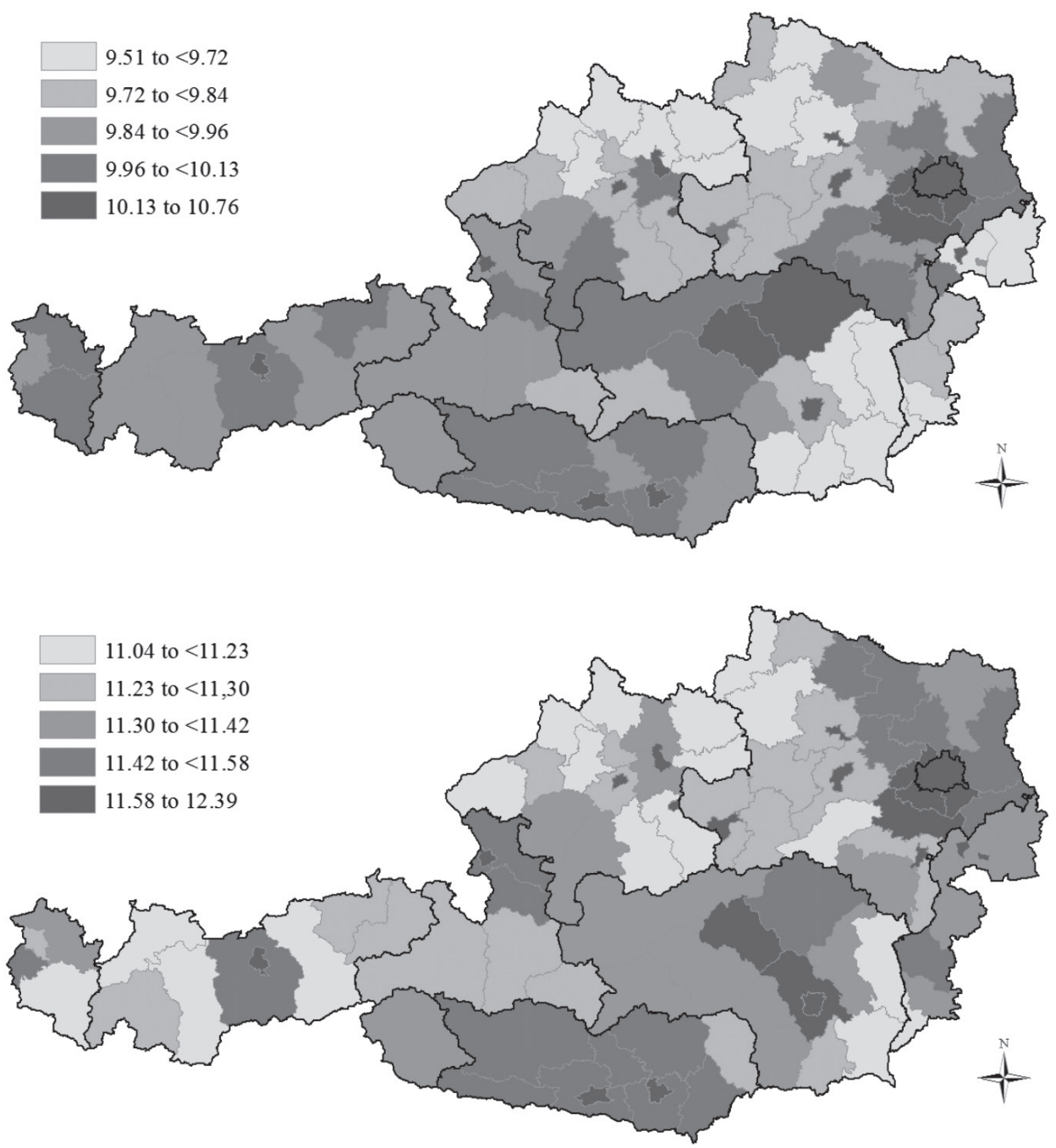

Data source: Calculated as defined by eq. (1)

Fig. 2a-2b: Regional average schooling years 1971 (above) and 2011 (below)

eastern regions have surpassed many western regions. Furthermore, some, though not all, suburban regions which surround capital cities have climbed upwards. This trend is also reflected by the correlation coefficient between schooling years and population density which increased from 0.62 in 1971 to 0.69 in 2011 . $^{8)}$ Furthermore, the educational expan-

8) The correlation coefficients with employee density differ slightly; they are given in Table 2 for each year. 
sion is captured by the fact that the lowest value in 2011 (11.04 schooling years) is higher than the highest value in 1971 (10.76 schooling years).
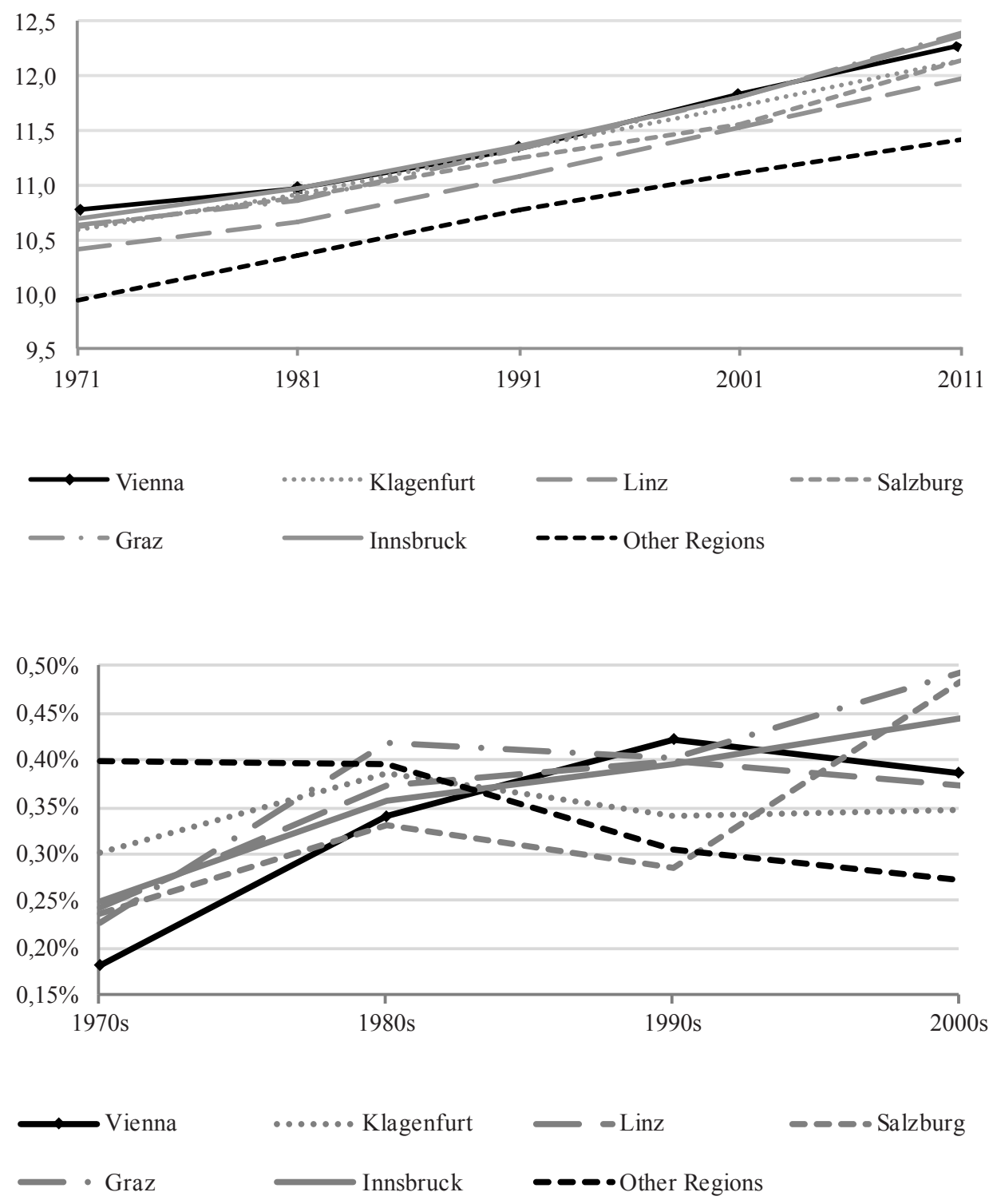

Data source: Calculated from the numbers yielded by eq. (1)

Fig. 3a-3b: Regional average schooling years 1971-2011 (above) and corresponding yearly average growth rates (below) 
Figures $3 \mathrm{a}$ and $3 \mathrm{~b}$ display average values of human capital for Vienna, the five major Austrian cities as defined by PALME (1995) and their corresponding average yearly growth rates in comparison to the rest of Austria. Concerning human capital development, a significant difference between urban and rural areas is apparent throughout the entire observation period. The gap decreases steadily until 1991. However, this trend is reversed in the following periods. It can therefore be assumed that the educational expansion of the 1970s and 1980s benefitted rural areas in particular and promoted convergence of human capital levels between cities and the rest of the country. The following periods show divergence: Major cities develop in a similar way as before while the rest of the country lags behind.

Looking at human capital growth, a similar picture can be seen. Regions other than Vienna and the major cities display relatively high growth rates during the 1970s and 1980s which drop significantly from the 1990s onwards. During the 2000s all major cities grow at a faster rate than the rest of the country, giving way to further divergence.

\begin{tabular}{|l|c|c|c|c|c|c|c|c|}
\hline & $\begin{array}{c}\text { Mean } \\
\text { (un- } \\
\text { weighted) }\end{array}$ & $\begin{array}{c}\text { Mean } \\
\text { (weight- } \\
\text { ed) }\end{array}$ & Median & $\begin{array}{c}\text { Inter- } \\
\text { quartile } \\
\text { range }\end{array}$ & Variance & $\begin{array}{c}\text { Variance } \\
\text { of log. } \\
\text { values }\end{array}$ & $\begin{array}{c}\text { Correla- } \\
\text { tion with } \\
\text { GVA }\end{array}$ & $\begin{array}{c}\text { Correla- } \\
\text { tion with } \\
\text { density }\end{array}$ \\
\hline 1971 & 9.96 & 10.25 & 9.91 & 0.32 & 0.08 & 0.00078 & 0.41 & 0.63 \\
\hline 1981 & 10.36 & 10.58 & 10.33 & 0.26 & 0.05 & 0.00047 & 0.39 & 0.60 \\
\hline 1991 & 10.78 & 10.98 & 10.75 & 0.21 & 0.04 & 0.00034 & 0.38 & 0.61 \\
\hline 2001 & 11.12 & 11.35 & 11.07 & 0.21 & 0.04 & 0.00035 & 0.45 & 0.70 \\
\hline 2011 & 11.43 & 11.73 & 11.36 & 0.27 & 0.07 & 0.00055 & 0.44 & 0.72 \\
\hline
\end{tabular}

Notes: GVA refers to gross value added per employee, density refers to employee density.

Data source: Calculated from the numbers yielded by eq. (1)

Tab. 2: Summary statistics

Table 2 shows national summary statistics for average years of schooling, which rose throughout the entire observation period. In contrast, measures of dispersion (interquartile range and variance) show a U-shaped development, decreasing until the 1990s and increasing afterwards. In similar vein, positive correlations between schooling years and GVA per employee as well as employee density can be observed throughout the entire observation period which, however, decreased at first and have both increased since the 1990s. This is indicative of an overall rise in educational levels independent of regional economic development during the early periods of the educational expansion, while educational development in the following period was more strongly connected to economic conditions. 
Austria

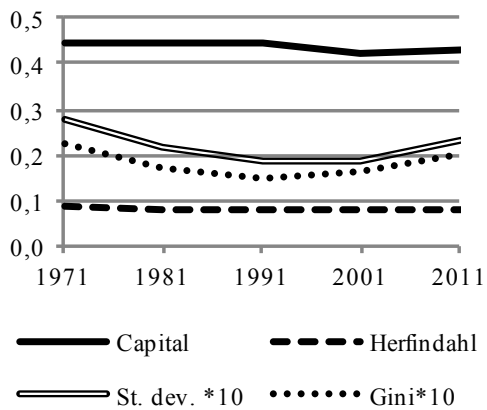

Carinthia

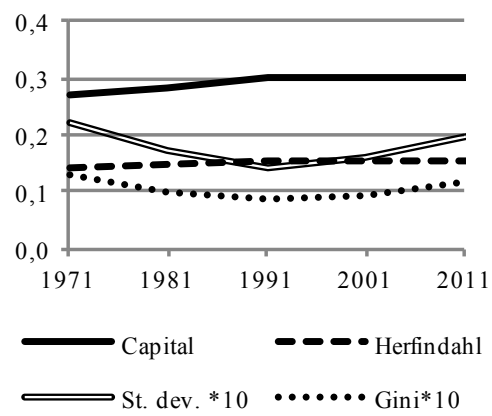

Salzburg

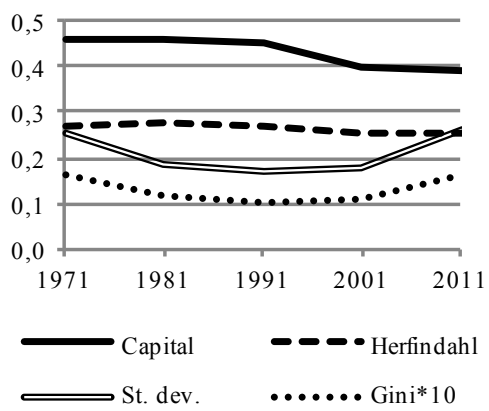

Burgenland

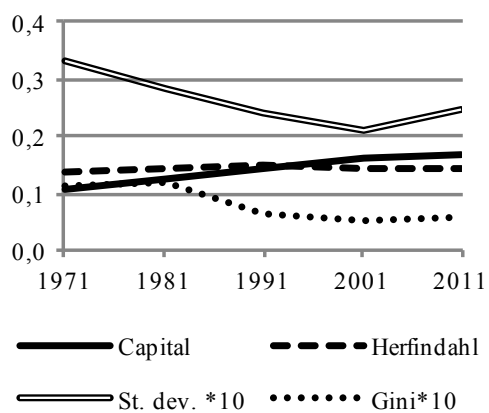

Lower Austria

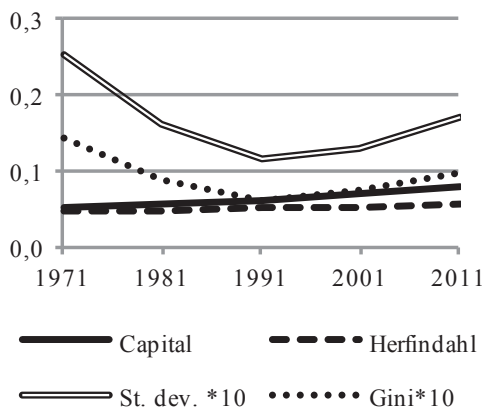

Styria

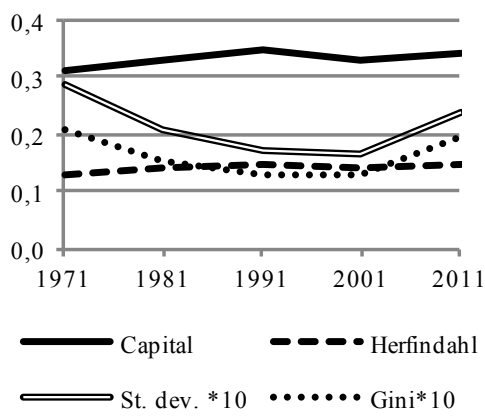

Data source: Calculated as documented in the text

Fig. 4a-4f: Interregional distribution of human capital endowments within Austria and its federal states 
Tyrol

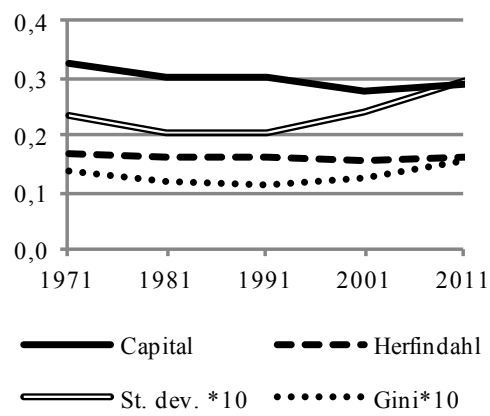

Upper Austria

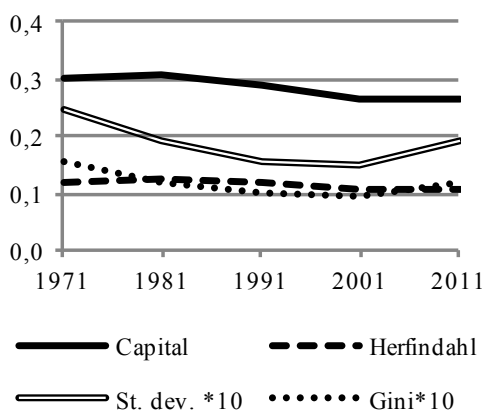

Vorarlberg

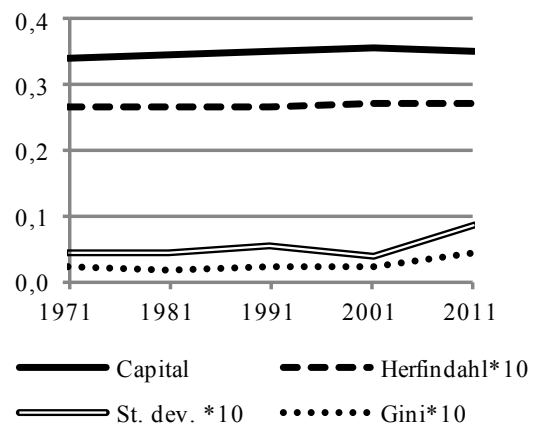

Data source: Calculated as documented in the text

Fig. 4g-4i: Interregional distribution of human capital endowments within Austria and its federal states

Figures $4 \mathrm{a}-4 \mathrm{i}$ display four measures of human capital distribution between and within the Austrian federal states and depict a similar development. "Capital" refers to the human capital share of the capital city, measured as:

$$
S_{i^{*}, t} P_{i^{*}, t} / \sum_{i=1}^{n^{*}} s_{i, t} P_{i, t}
$$

where $P$ symbolises the number of employees, $n^{*}$ denotes the number of spatial units within a federal state or the nation state and $i *$ the respective capital city. "Herfindahl" equals the Herfindahl index of $s_{i, t}$ " "St. dev" is the non-weighted standard deviation of the logarithmised values of $s_{i, t}$ and "Gini" is the Gini coefficient of $s_{i, t}$, where regional population numbers are taken as frequency measures.

At the national level, a decrease in inequality can be observed from 1971 to 1991 followed by a slight increase during the 1990 s and a stronger one during the 2000 s, as is 
also evident in Table 2. Most federal states show a similar pattern, with Gini coefficients and standard deviations dropping throughout the 1970s and 1980s and rising again in later periods. The concentration of human capital in Vienna remains at a relatively high and stable level throughout the entire observation period, while concentrations of human capital in federal state capital cities have decreased in some states (Salzburg, Tyrol [Tirol], Upper Austria [Oberösterreich]) and slightly increased in others (Burgenland, Carinthia [Kärnten], Styria [Steiermark]). Lower Austria [Niederösterreich] shows a remarkably low concentration of human capital within its capital city which is, however, probably due to Vienna's demand for high-skilled labour. Therefore, it is likely that Vienna - which is surrounded by suburban regions which are part of Lower Austria and which also served as Lower Austria's seat of government until 1996 - absorbs a high share of Lower Austria's high-skilled persons.

\section{Cross-sectional regressions}

This section summarises the main results obtained from cross-sectional regressions, followed by panel regressions in the next section. The objective of the cross-sectional analysis is to identify the correlations between human capital endowments and current economic structure and technology. The regression specification takes the form

$$
s_{i, t}=\alpha+\beta_{1} x_{1, i, t}+\ldots+\beta_{k} x_{k, i, t}+\varepsilon_{i, t}
$$

where the $x$ s represent the $k$ explanatory variables, with the $\beta$ s representing the corresponding coefficients. $\alpha$ is the intercept, $\varepsilon_{i, t}$ is an error term. In addition to the coefficients' values, we include the Moran's $I$ value of the residuals, where neighbourhood is defined as two districts sharing a common border. ${ }^{9)}$ The results for the five points in time for which data are available are given in Table 3.

The intercept is consistently slightly lower than the dependent variable's unweighted mean values, as can be seen by comparing the respective coefficients with the numbers given in Table 2. However, the differences are decreasing until 1991 and then start to increase again, with the intercept for 2011 being lower than for 2001 despite a higher mean. From this it follows that, at first, the explanation power of the national development regarding regional human capital endowments increases until 1991. After that, region-specific characteristics are becoming more important again. This finding, too, corresponds to Table 2 which indicates a decrease of interregional inequality until 1991 and a subsequent increase. Judging from the adjusted $R^{2}$ values the explanation power is remarkably high in general, but nevertheless follows a similar U-shaped pattern as the intercept.

Furthermore, it is interesting to note that the geographical characteristics, density, Comecon and suburbia, play a statistically significant role in 1971 only. The behaviour of

\footnotetext{
9) For a discussion on the method, see GoodchiLd (1986).
} 


\begin{tabular}{|c|c|c|c|c|c|}
\hline & 1971 & 1981 & 1991 & 2001 & 2011 \\
\hline Intercept & $\begin{array}{c}9.4085 * * * \\
(0.2450)\end{array}$ & $\begin{array}{c}10.0113 * * * \\
(0.3453)\end{array}$ & $\begin{array}{c}10.6779 * * * \\
(0.2668)\end{array}$ & $\begin{array}{c}11.0267 * * * \\
(0.2800)\end{array}$ & $\begin{array}{c}10.7737 * * * \\
(0.3480)\end{array}$ \\
\hline Density & $\begin{array}{c}-0.0124 * * * \\
(0.0041)\end{array}$ & $\begin{array}{c}-0.0064 \\
(0.0053)\end{array}$ & $\begin{array}{l}-0.0040 \\
(0.0054)\end{array}$ & $\begin{array}{c}-0.0027 \\
(0.0055)\end{array}$ & $\begin{array}{c}0.0079 \\
(0.0094)\end{array}$ \\
\hline Comecon & $\begin{array}{l}0.0475^{*} \\
(0.0269)\end{array}$ & $\begin{array}{c}0.0411 \\
(0.0384)\end{array}$ & $\begin{array}{l}-0.0286 \\
(0.0377)\end{array}$ & $\begin{array}{l}-0.0422 \\
(0.0294)\end{array}$ & $\begin{array}{l}-0.0307 \\
(0.0321)\end{array}$ \\
\hline Suburbia & $\begin{array}{l}0.0611 * \\
(0.0335)\end{array}$ & $\begin{array}{c}0.0517 \\
(0.0390)\end{array}$ & $\begin{array}{c}0.0539 \\
(0.0428)\end{array}$ & $\begin{array}{c}0.0715 \\
(0.0483)\end{array}$ & $\begin{array}{c}0.0339 \\
(0.0603)\end{array}$ \\
\hline Productivity & $\begin{array}{c}0.0172 \\
(0.0795)\end{array}$ & $\begin{array}{l}-0.0359 \\
(0.0755)\end{array}$ & $\begin{array}{c}0.1017 \\
(0.0658)\end{array}$ & $\begin{array}{c}0.0446 \\
(0.0574)\end{array}$ & $\begin{array}{c}0.0814 \\
(0.0551)\end{array}$ \\
\hline Unemployment & $\begin{array}{c}-0.5389 \\
(1.9285)\end{array}$ & $\begin{array}{c}0.7482 \\
(1.4037)\end{array}$ & $\begin{array}{c}0.0408 \\
(0.9156)\end{array}$ & $\begin{array}{c}0.8218 \\
(0.8524)\end{array}$ & $\begin{array}{l}-1.2385 \\
(0.7699)\end{array}$ \\
\hline Low tech & $\begin{array}{c}0.0918 \\
(0.1551)\end{array}$ & $\begin{array}{c}-0.6144 * * \\
(0.2431)\end{array}$ & $\begin{array}{c}-1.0626 * * * \\
(0.3956)\end{array}$ & $\begin{array}{c}-1.0744 * * \\
(0.4618)\end{array}$ & $\begin{array}{l}-0.5747 \\
(0.6501)\end{array}$ \\
\hline Med.-low tech & $\begin{array}{c}0.7714 * * * \\
(0.1626)\end{array}$ & $\begin{array}{c}0.3164 \\
(0.2744)\end{array}$ & $\begin{array}{l}-0.0670 \\
(0.2950)\end{array}$ & $\begin{array}{l}-0.5292 * \\
(0.2986)\end{array}$ & $\begin{array}{l}-0.0969 \\
(0.4691)\end{array}$ \\
\hline Med.-high tech & $\begin{array}{c}0.9622 * * * \\
(0.1892)\end{array}$ & $\begin{array}{c}0.4385 \\
(0.3050)\end{array}$ & $\begin{array}{c}0.0609 \\
(0.3325)\end{array}$ & $\begin{array}{l}-0.1081 \\
(0.3341)\end{array}$ & $\begin{array}{c}0.0800 \\
(0.4785)\end{array}$ \\
\hline High tech & $\begin{array}{l}-0.1817 \\
(0.8252)\end{array}$ & $\begin{array}{c}-1.2820 * * \\
(0.5209)\end{array}$ & $\begin{array}{c}0.5975 \\
(0.5821)\end{array}$ & $\begin{array}{l}0.8446 * \\
(0.4868)\end{array}$ & $\begin{array}{c}5.1965^{* * * *} \\
(1.5291)\end{array}$ \\
\hline KIS & $\begin{array}{c}3.7515 * * * \\
(0.4530) \\
\end{array}$ & $\begin{array}{c}2.2365 * * * \\
(0.4690)\end{array}$ & $\begin{array}{c}1.8878 * * * \\
(0.4343) \\
\end{array}$ & $\begin{array}{c}1.8605 * * * \\
(0.4041)\end{array}$ & $\begin{array}{c}1.9305^{* * * *} \\
(0.4312)\end{array}$ \\
\hline LKIS & $\begin{array}{c}1.3339 * * * \\
(0.1788)\end{array}$ & $\begin{array}{c}1.0462 * * * \\
(0.2210)\end{array}$ & $\begin{array}{c}0.6745 * * * \\
(0.2216)\end{array}$ & $\begin{array}{c}0.0768 \\
(0.2507)\end{array}$ & $\begin{array}{c}1.0603 * * * \\
(0.3685)\end{array}$ \\
\hline Small firms & $\begin{array}{c}-0.5120 * * * \\
(0.1665)\end{array}$ & $\begin{array}{c}-0.6163 * * * \\
(0.2116) \\
\end{array}$ & $\begin{array}{c}-0.5280 * * * \\
(0.1989)\end{array}$ & $\begin{array}{c}-0.4517 * * \\
(0.2066) \\
\end{array}$ & $\begin{array}{l}-0.0667 \\
(0.1074) \\
\end{array}$ \\
\hline Large firms & $\begin{array}{l}>0.0000 \\
(0.0002)\end{array}$ & $\begin{array}{l}-0.0001 \\
(0.0002)\end{array}$ & $\begin{array}{c}-0.0003 \\
(0.0002)\end{array}$ & $\begin{array}{l}-0.0001 \\
(0.0003)\end{array}$ & $\begin{array}{c}-0.0006 * * \\
(0.0003)\end{array}$ \\
\hline Specialisation & $\begin{array}{l}-0.0512 \\
(0.0910) \\
\end{array}$ & $\begin{array}{l}-0.0884 \\
(0.1239)\end{array}$ & $\begin{array}{c}0.1875 \\
(0.1223)\end{array}$ & $\begin{array}{l}-0.0298 \\
(0.1336)\end{array}$ & $\begin{array}{c}0.0360 \\
(0.1722)\end{array}$ \\
\hline Universities & $\begin{array}{c}0.0337 \\
(0.0230) \\
\end{array}$ & $\begin{array}{c}0.0351 \\
(0.0231) \\
\end{array}$ & $\begin{array}{l}0.0492 * \\
(0.0264)\end{array}$ & $\begin{array}{c}0.0212 \\
(0.0240)\end{array}$ & $\begin{array}{c}0.0564 * * \\
(0.0218)\end{array}$ \\
\hline Moran's I & $0.3904 * * *$ & $0.3913 * * *$ & $0.4048 * * *$ & $0.3373 * * *$ & $0.2040 * * *$ \\
\hline$F$-statistic & 61.16 & 23.12 & 16.79 & 22.02 & 22.06 \\
\hline$\sigma^{2}$ & 0.0079 & 0.0118 & 0.0120 & 0.0106 & 0.0179 \\
\hline$R^{2}$ & 0.9170 & 0.8069 & 0.7521 & 0.7991 & 0.7995 \\
\hline
\end{tabular}

Notes: The estimations have been carried out with $R$ by application of the packages lmtest, spdep and sandwich. White homoscedastic standard errors of the regression's coefficients are in parentheses. Moran's $I$ refers to the respective values of the residuals, where $p$-values are based on 10,000 sampled raw parameter estimates. $*, * *, * * *$ correspond to $p$-values of $0.1,0.05$ and 0.01 , respectively. $\sigma^{2}$ and $R^{2}$ refer to the residual variance and adjusted coefficient of determination, respectively.

Tab. 3: Cross-sectional estimations 
density is of particular interest, as it shows no significant positive effect despite the high positive correlation with the dependent number as given in Table 2. Furthermore, the Moran's I values of the residuals are relatively high, highly significant and remarkably similar over the observation period. This indicates that the dependent variable is also influenced by relations across neighbouring districts.

The fundamental indicators of economic performance, productivity and unemployment, seem to play no role at any point in time. In contrast, the technology levels of the manufacturing sector play a decisive yet varying role. In particular, the expected negative effect of low technology manufacturing industries (low tech) is observable not before 1981, whereas high technology manufacturing industries (high tech) have a positive impact not before 1991. In this context it should be mentioned that the agricultural sector was still relatively large in 1971 (14.2\% of employed people in Austria, with some districts reaching over $50 \%$ ). This explains the highly significant and strong positive effects of the two medium technology categories (med.-low tech and med.-high tech), assuming that the industrial sector demands higher skills.

In contrast to the manufacturing sector, services display consistent results for the whole observation period, with both KIS and LKIS being positively correlated with schooling in each regression. A closer look, however, reveals that (i) the coefficients of KIS are threefold as large compared to LKIS and that (ii) both coefficients' values decrease rapidly during the first half of the observation period. These developments are probably mainly due to the educational expansion: If spatial inequality regarding education decreases, then, ceteris paribus, a spatial concentration of high-grade services in particular will be correlated with average regional education to a lesser extent.

Concerning the remaining variables, small firms display a negative correlation until 2001, after that this role belongs to large firms. As discussed in Section 2, especially cost-conscious small firms in Austria demand specific skills. These are not necessarily positively correlated with schooling years and are probably of particular relevance for the tourism sector, as it is in particular the strength of the tourism sector that is related to high demand for low skills in Austria (JANGER 2013). Specialisation as such seems to have no effect, whereas universities is positive throughout. Considering that (i) only a handful of districts actually hosts universities and that (ii) the standard errors are low for each year, it can be concluded that the presence of universities affects regional schooling levels positively.

\section{Panel regressions}

The estimations of the preceding section reveal which factors are correlated with regional human capital endowments at particular points in time, but they provide limited information regarding the dynamics of developments. In what follows, panel regressions are applied in order to examine the impact of the various variables on regional schooling growth rates. The Moran's $I$ values for spatial autocorrelation of the residuals are also estimated for each panel regression. 
The first regression is a fixed effects regression:

$$
g_{i, t, t-1}=\beta_{1} z_{1, i, t-1}+\ldots+\beta_{k} z_{k, i, t-1}+\varepsilon_{i, t}-\bar{\varepsilon}_{i}
$$

where

$$
\begin{gathered}
g_{i, t, t-1}=\ln \left(s_{i, t} / s_{i, t-1}\right)-(1 / 4) \sum_{t=2}^{5} \ln \left(s_{i, t} / s_{i, t-1}\right) \\
z_{q, i, t-1}=\ln x_{q, i, t-1}-(1 / 4) \sum_{t=2}^{5} \ln x_{q, i, t-1}
\end{gathered}
$$

with $x_{q}$ representing the $q$ th of the $k$ explanatory variables and $\varepsilon$ representing an error term, $\bar{\varepsilon}$ its average. The explanatory variables are the same as in the cross-sectional specifications except for dummy variables, as they do not change over time and are hence captured by the fixed effects. Also note that on both sides of eq. (3) the variables are logged, therefore the estimated coefficients can be interpreted as elasticities of the dependent variable with respect to the explanatory variables.

Furthermore, the regression includes a time dummy that equals one for the years when Austria was a member of the European Union. SARDAdVAR \& ReInER (2015) find some strong interaction effects of this dummy with other variables on growth of total employment and high-skilled employment share which is explained by the authors by a change of framework conditions (ibid.). The summary statistics of Table 2 and the cross-sectional results of Table 3 display trend reversals that emerged somewhere during the 1990s in the present context, too, although it is not clear whether they are due to EU membership as such. ${ }^{10)}$

The results corresponding to eq. (3) are presented in columns (1) and (2) of Table 4. It can be seen that the variables' impact on growth differs substantially from their correlations with current endowments as displayed in Table 3 . The time dummy as such is negative which coincides with a decreasing growth rate of schooling years. Density is positive, but the interaction with the time dummy reveals that this effect is more prevalent in later years. This indicates that agglomeration effects became stronger in later years, i.e. human capital concentrating in urban and suburban regions after convergence during the first half of the observation period. A similar effect of universities underlines this interpretation and reveals one possible reason as most Austrian universities and universities of applied sciences are located in urban areas.

The panel estimations also reveal an unambiguously negative impact of the presence of low and medium-low technology manufacturing industries as well as LKIS on human capital growth, which is perhaps the most striking result. The impact of high tech, however, is not as clear and even negative when interacting. The variable specialisation behaves similarly. In addition, small firms, while negatively correlated with current human capital endowments, has a positive effect on human capital growth. This impact, however, disappears when controlling for time as in column (2). In contrast to the cross-sectional regressions no spatial autocorrelation can be detected.

\footnotetext{
10) One obvious effect is the freedom of movement for workers in the European Union (EU) which eased both emigration and immigration. It should also be mentioned that the dissolution of the Comecon, which eased emigration from its former member states, coincides with Austria's economic integration with the EU (which preceded actual membership, e.g. by signing accession to the European Economic Area in 1992).
} 


\begin{tabular}{|c|c|c|c|c|c|c|}
\hline & \multicolumn{4}{|c|}{ Fixed effects } & \multicolumn{2}{|c|}{ First difference } \\
\hline & (1) & (2) & (3) & (4) & (5) & (6) \\
\hline Intercept & & & & & $\begin{array}{c}0.0278 * * * \\
(0.0016)\end{array}$ & $\begin{array}{c}0.0283 * * * \\
(0.0017)\end{array}$ \\
\hline Schooling & & & $\begin{array}{c}-0.6583 * * * \\
(0.0761)\end{array}$ & $\begin{array}{c}-0.5305 * * * \\
(0.0721)\end{array}$ & & \\
\hline Density & $\begin{array}{c}0.0164 * * \\
(0.0076)\end{array}$ & $\begin{array}{l}-0.0052 \\
(0.0062)\end{array}$ & $\begin{array}{c}0.0178^{* * * *} \\
(0.0055)\end{array}$ & $\begin{array}{c}0.0110 * * \\
(0.0054)\end{array}$ & $\begin{array}{c}0.0024 \\
(0.0054) \\
\end{array}$ & $\begin{array}{c}0.0004 \\
(0.0058) \\
\end{array}$ \\
\hline Productivity & $\begin{array}{l}-0.0011 \\
(0.0025)\end{array}$ & $\begin{array}{c}0.0035 \\
(0.0025)\end{array}$ & $\begin{array}{c}0.0178^{* * * *} \\
(0.0031)\end{array}$ & $\begin{array}{c}0.0149 * * * \\
(0.0028)\end{array}$ & $\begin{array}{l}0.0033 * \\
(0.0019)\end{array}$ & $\begin{array}{c}0.0021 \\
(0.0025)\end{array}$ \\
\hline Unemployment & $\begin{array}{l}-0.0002 \\
(0.0028)\end{array}$ & $\begin{array}{l}0.0033^{*} \\
(0.0020)\end{array}$ & $\begin{array}{c}0.0017 \\
(0.0019) \\
\end{array}$ & $\begin{array}{c}0.0021 \\
(0.0018) \\
\end{array}$ & $\begin{array}{c}-0.0032 * \\
(0.0018)\end{array}$ & $\begin{array}{l}-0.0027 \\
(0.0019) \\
\end{array}$ \\
\hline Low tech & $\begin{array}{c}-0.0106^{*} \\
(0.0058)\end{array}$ & $\begin{array}{c}-0.0100 * * \\
(0.0049)\end{array}$ & $\begin{array}{c}-0.0106 * * \\
(0.0043)\end{array}$ & $\begin{array}{c}-0.0097 * * \\
(0.0039)\end{array}$ & $\begin{array}{l}-0.0002 \\
(0.0028)\end{array}$ & $\begin{array}{c}0.0023 \\
(0.0022)\end{array}$ \\
\hline Med.-low tech & $\begin{array}{c}-0.0038 * * \\
(0.0017)\end{array}$ & $\begin{array}{c}-0.0037 * * \\
(0.0017)\end{array}$ & $\begin{array}{c}-0.0038 * * * \\
(0.0014)\end{array}$ & $\begin{array}{c}-0.0030 * \\
(0.0015)\end{array}$ & $\begin{array}{c}0.0007 * * * \\
(0.0001)\end{array}$ & $\begin{array}{c}0.0032 * * \\
(0.0012)\end{array}$ \\
\hline Med.-high tech & $\begin{array}{c}0.0002 \\
(0.0009)\end{array}$ & $\begin{array}{l}-0.0007 \\
(0.0014)\end{array}$ & $\begin{array}{c}-0.0011 \\
(0.0009) \\
\end{array}$ & $\begin{array}{l}-0.0004 \\
(0.0013)\end{array}$ & $\begin{array}{l}-0.0005 \\
(0.0006)\end{array}$ & $\begin{array}{l}-0.0005 \\
(0.0007)\end{array}$ \\
\hline High tech & $\begin{array}{l}-0.0004 \\
(0.0003) \\
\end{array}$ & $\begin{array}{c}0.0009 * * \\
(0.0004)\end{array}$ & $\begin{array}{l}-0.0002 \\
(0.0002) \\
\end{array}$ & $\begin{array}{c}0.0003 \\
(0.0004) \\
\end{array}$ & $\begin{array}{c}0.0001 \\
(0.0001) \\
\end{array}$ & $\begin{array}{l}-0.0002 \\
(0.0002) \\
\end{array}$ \\
\hline KIS & $\begin{array}{l}-0.0027 \\
(0.0057)\end{array}$ & $\begin{array}{l}-0.0034 \\
(0.0053)\end{array}$ & $\begin{array}{c}0.0234 * * * \\
(0.0062)\end{array}$ & $\begin{array}{c}0.0206 * * * \\
(0.0059) \\
\end{array}$ & $\begin{array}{c}0.0231 * * * \\
(0.0038) \\
\end{array}$ & $\begin{array}{c}0.0223 * * * \\
(0.0037)\end{array}$ \\
\hline LKIS & $\begin{array}{c}-0.0311 * * * \\
(0.0062)\end{array}$ & $\begin{array}{c}-0.0170 * * * \\
(0.0054)\end{array}$ & $\begin{array}{c}-0.0178 * * * \\
(0.0057)\end{array}$ & $\begin{array}{c}-0.0098 * * \\
(0.0046) \\
\end{array}$ & $\begin{array}{c}0.0257 * * * \\
(0.0035)\end{array}$ & $\begin{array}{c}0.0322 * * * \\
(0.0040) \\
\end{array}$ \\
\hline Small firms & $\begin{array}{c}0.0289 * * * \\
(0.0092)\end{array}$ & $\begin{array}{c}0.0019 \\
(0.0073) \\
\end{array}$ & $\begin{array}{c}0.0067 \\
(0.0078) \\
\end{array}$ & $\begin{array}{c}0.0062 \\
(0.0068)\end{array}$ & $\begin{array}{c}-0.0130 * * * \\
(0.0037)\end{array}$ & $\begin{array}{c}-0.0175^{* * *} * \\
(0.0059)\end{array}$ \\
\hline Large firms & $\begin{array}{l}-0.0001 \\
(0.0013)\end{array}$ & $\begin{array}{c}0.0007 \\
(0.0012) \\
\end{array}$ & $\begin{array}{c}0.0005 \\
(0.0012) \\
\end{array}$ & $\begin{array}{c}0.0012 \\
(0.0011) \\
\end{array}$ & $\begin{array}{c}0.0004 \\
(0.0011)\end{array}$ & $\begin{array}{c}0.0001 \\
(0.0012) \\
\end{array}$ \\
\hline Specialisation & $\begin{array}{l}-0.0066 \\
(0.0048) \\
\end{array}$ & $\begin{array}{c}0.0057 \\
(0.0045) \\
\end{array}$ & $\begin{array}{l}-0.0053 \\
(0.0040) \\
\end{array}$ & $\begin{array}{c}0.0065 \\
(0.0042)\end{array}$ & $\begin{array}{l}0.0058 * \\
(0.0034)\end{array}$ & $\begin{array}{c}0.0072 * * \\
(0.0036)\end{array}$ \\
\hline Universities & $\begin{array}{l}0.0018 * \\
(0.0010)\end{array}$ & $\begin{array}{l}-0.0006 \\
(0.0009)\end{array}$ & $\begin{array}{c}0.0017 * * \\
(0.0008)\end{array}$ & $\begin{array}{l}-0.0014 \\
(0.0012)\end{array}$ & $\begin{array}{l}0.0010 * \\
(0.0006)\end{array}$ & $\begin{array}{l}-0.0013 \\
(0.0010)\end{array}$ \\
\hline Time dummy & $\begin{array}{c}-0.0104 * * * \\
(0.0019)\end{array}$ & $\begin{array}{l}-0.0327 \\
(0.0285)\end{array}$ & $\begin{array}{l}-0.0025 \\
(0.0016)\end{array}$ & $\begin{array}{l}0.2724 * \\
(0.1473) \\
\end{array}$ & $\begin{array}{c}-0.0063 * * * \\
(0.0010)\end{array}$ & $\begin{array}{c}-0.0458 * * \\
(0.0240)\end{array}$ \\
\hline $\begin{array}{l}\text { Time dummy * } \\
\text { schooling }\end{array}$ & & & & $\begin{array}{c}-0.1273 * * \\
(0.0632)\end{array}$ & & \\
\hline $\begin{array}{l}\text { Time dummy * } \\
\text { density }\end{array}$ & & $\begin{array}{c}0.0033^{* * *} * \\
(0.0010) \\
\end{array}$ & & $\begin{array}{c}0.0010 \\
(0.0010)\end{array}$ & & $\begin{array}{c}0.0001 \\
(0.0010) \\
\end{array}$ \\
\hline $\begin{array}{l}\text { Time dummy * } \\
\text { productivity }\end{array}$ & & $\begin{array}{c}0.0002 \\
(0.0033) \\
\end{array}$ & & $\begin{array}{c}0.0022 \\
(0.0036) \\
\end{array}$ & & $\begin{array}{l}0.0067 * \\
(0.0041)\end{array}$ \\
\hline $\begin{array}{l}\text { Time dummy * } \\
\text { unemployment }\end{array}$ & & $\begin{array}{l}-0.0040 \\
(0.0029) \\
\end{array}$ & & $\begin{array}{l}-0.0034 \\
(0.0023) \\
\end{array}$ & & $\begin{array}{l}-0.0006 \\
(0.0020) \\
\end{array}$ \\
\hline $\begin{array}{l}\text { Time dummy * } \\
\text { low tech }\end{array}$ & & $\begin{array}{c}0.0056 * * \\
(0.0024)\end{array}$ & & $\begin{array}{l}-0.0001 \\
(0.0026)\end{array}$ & & $\begin{array}{l}-0.0035^{*} \\
(0.0020)\end{array}$ \\
\hline $\begin{array}{l}\text { Time dummy * } \\
\text { med.-low tech }\end{array}$ & & $\begin{array}{c}0.0004 \\
(0.0012) \\
\end{array}$ & & $\begin{array}{l}-0.0019 \\
(0.0012) \\
\end{array}$ & & $\begin{array}{c}-0.0040 * * * \\
(0.0011)\end{array}$ \\
\hline
\end{tabular}




\begin{tabular}{|c|c|c|c|c|c|c|}
\hline & \multicolumn{4}{|c|}{ Fixed effects } & \multicolumn{2}{|c|}{ First difference } \\
\hline & (1) & (2) & (3) & (4) & (5) & (6) \\
\hline $\begin{array}{l}\text { Time dummy * } \\
\text { med.-high tech }\end{array}$ & & $\begin{array}{l}-0.0005 \\
(0.0012)\end{array}$ & & $\begin{array}{l}-0.0005 \\
(0.0012) \\
\end{array}$ & & $\begin{array}{c}0.0007 \\
(0.0009) \\
\end{array}$ \\
\hline $\begin{array}{l}\text { Time dummy * } \\
\text { high tech }\end{array}$ & & $\begin{array}{c}-0.0007 * * \\
(0.0003)\end{array}$ & & $\begin{array}{l}-0.0004 \\
(0.0003) \\
\end{array}$ & & $\begin{array}{c}0.0002 \\
(0.0002) \\
\end{array}$ \\
\hline $\begin{array}{l}\text { Time dummy * } \\
\text { KIS }\end{array}$ & & $\begin{array}{c}-0.0103 * * \\
(0.0042)\end{array}$ & & $\begin{array}{c}0.0029 \\
(0.0042) \\
\end{array}$ & & $\begin{array}{l}-0.0056 \\
(0.0043)\end{array}$ \\
\hline $\begin{array}{l}\text { Time dummy * } \\
\text { LKIS }\end{array}$ & & $\begin{array}{c}0.0047 \\
(0.0043)\end{array}$ & & $\begin{array}{l}-0.0043 \\
(0.0042) \\
\end{array}$ & & $\begin{array}{c}-0.0165^{* * *} \\
(0.0047)\end{array}$ \\
\hline $\begin{array}{l}\text { Time dummy * } \\
\text { small firms }\end{array}$ & & $\begin{array}{l}-0.0054 \\
(0.0056) \\
\end{array}$ & & $\begin{array}{l}-0.0096 * \\
(0.0052)\end{array}$ & & $\begin{array}{c}0.0035 \\
(0.0059) \\
\end{array}$ \\
\hline $\begin{array}{l}\text { Time dummy * } \\
\text { large firms }\end{array}$ & & $\begin{array}{l}-0.0001 \\
(0.0010) \\
\end{array}$ & & $\begin{array}{l}-0.0004 \\
(0.0011)\end{array}$ & & $\begin{array}{c}0.0008 \\
(0.0011) \\
\end{array}$ \\
\hline $\begin{array}{l}\text { Time dummy * } \\
\text { specialisation }\end{array}$ & & $\begin{array}{l}-0.0091 * \\
(0.0054)\end{array}$ & & $\begin{array}{c}-0.0105 * * \\
(0.0041)\end{array}$ & & $\begin{array}{l}-0.0075^{*} \\
(0.0050)\end{array}$ \\
\hline $\begin{array}{l}\text { Time dummy * } \\
\text { universities }\end{array}$ & & $\begin{array}{l}0.0015^{*} \\
(0.0009)\end{array}$ & & $\begin{array}{c}0.0029 * * * \\
(0.0011)\end{array}$ & & $\begin{array}{c}0.0028 * * * \\
(0.0010)\end{array}$ \\
\hline $\begin{array}{l}\text { Moran's } I \\
1971 / 1981\end{array}$ & -0.1632 & -0.0765 & -0.0795 & -0.0375 & 0.0095 & 0.0369 \\
\hline $\begin{array}{l}\text { Moran's I } \\
1981 / 1991 \\
\end{array}$ & -0.0694 & 0.0060 & -0.0561 & 0.0137 & -0.1074 & -0.0940 \\
\hline $\begin{array}{l}\text { Moran's I } \\
1991 / 2001\end{array}$ & -0.0226 & -0.1082 & 0.0010 & -0.0511 & -0.0017 & -0.0224 \\
\hline $\begin{array}{l}\text { Moran's I } \\
2001 / 2011\end{array}$ & -0.1342 & -0.1351 & -0.0723 & -0.0801 & -0.1435 & -0.1332 \\
\hline$F$-statistic & 28.15 & 21.79 & 47.75 & 31.40 & 35.56 & 22.33 \\
\hline$\sigma^{2}$ & 0.0000 & 0.0000 & 0.0000 & 0.0000 & 0.0000 & 0.0000 \\
\hline$R^{2}$ & 0.5820 & 0.6854 & 0.5109 & 0.5229 & 0.5671 & 0.6216 \\
\hline
\end{tabular}

Notes: The estimations have been carried out with $R$ using the plm and splm packages. White homoscedastic standard errors of the regression's coefficients are in parentheses. Moran's $I$ refers to the respective values of the residuals, where $p$-values are based on 10,000 sampled raw parameter estimates. *,**,*** correspond to $p$-values of $0.1,0.05$ and 0.01 , respectively. $\sigma^{2}$ and $R^{2}$ refer to the residual variance and adjusted coefficient of determination, respectively.

Tab. 4: Panel estimations

Columns (3) and (4) display the same estimations with regional schooling levels of the preceding period added as an additional explanatory variable:

$$
g_{i, t, t-1}=\beta_{1} \ln s_{i, t-1}+\beta_{2} z_{1, i, t-1}+\ldots+\beta_{k} z_{k, i, t-1}+\varepsilon_{i, t}-\bar{\varepsilon}_{i}
$$


The respective coefficients of schooling are clearly negative, large in value and highly significant. This result strongly supports the recognition of (i) an overall convergence of human capital endowments which, however, (ii) slowed down since the 1990s. Furthermore, controlling for preceding schooling levels brings out the crucial roles of density and productivity which hints at interregional migration of human capital suppliers to thriving regions. In addition and perhaps most importantly, KIS is now positive and highly significant, while the impact of universities is particularly strong since the 1990s. The Moran's I values are non-significant in each case.

The fixed effects regressions are accompanied by first difference regressions:

$$
\Delta \ln s_{i, t, t-1}=\alpha_{0}+\beta_{1} \Delta \ln x_{1, i, t, t-1}+\ldots+\beta_{k} \Delta \ln x_{k, i, t, t-1}+\Delta \varepsilon_{i, t}
$$

where the $\Delta$ s represent changes in the variables' values between $t-1$ and $t$. In contrast to columns (1)-(4) of Table 4, eq. (5) estimates the effect of simultaneous changes in the explanatory variables on changes in the dependent variable, with the results being shown in columns (5) and (6) of Table 4. Therefore, while LKIS and med.-low tech have negative impacts on human capital growth, simultaneous growth has positive effects. In contrast, the effects of changes in the manufacturing industries are much weaker. Specialisation and universities change is both positive, while small firms change is negative. Again, there is no indication of spatial dependence.

To summarise, KIS, high tech and universities are positively correlated with current human capital endowments, but only KIS and, to a lesser extent, universities display an impact on regional human capital growth. Manufacturing and services industries that demand only low skills display negative impacts. Therefore, the results provide evidence that, on the one hand, economic structure matters. On the other hand, there is no evidence for a specific, perhaps self-enforcing human capital growth effect as caused by the location of high technology firms.

The convergence effect indicates that the strongest effect on human capital growth is caused by national education policies, while simultaneously urban areas and thriving regions were able to attract human capital, i.e. internal as well as international migrants with high schooling levels. Furthermore, while the cross-sectional regressions reveal robust positive values of spatial autocorrelation of the residuals, no such effect can be found in the panel regressions. Therefore, while the spatial distribution of human capital is affected by neighbourhood values, its development over time is captured by economic changes that occur within the regions. The latter, however, may be spatially autocorrelated, calling for subsequent research.

\section{Conclusions}

Austria has experienced a remarkable increase in human capital endowments per worker as measured by average schooling years. From 1971-2011, this number has increased by almost 1.5 years per employee. During that time, Austria underwent an evolution from an industrialised country with low innovative activity to an economy that is on the edge of 
joining the European Union's countries which are classified as “innovation leaders", with innovation performance already, as of now, found above that of the EU average (AIGINGER et al. 2009; EuropeAn COMMISsion 2015). The present paper has tackled the question what determines the distribution of human capital across the 99 districts of Austria. The key questions as deducted from the literature were (i) whether knowledge intensity of production has a positive impact on regional human capital endowments and (ii) whether human capital endowments converge across regions.

An explorative study firstly shows that educational attainments have considerably increased since 1971. However, this increase slowed down since 1991. Furthermore, as indicated by various indicators, until 1991 spatial inequality with respect to human capital endowments decreased and then increased again, displaying a U-shaped development. This result holds for Austria as a whole as well as for most of the federal states.

The explanatory study is split into two parts. The first part features results from cross-sectional regressions in which regional average schooling years of the employees serve as dependent variable. The estimations reveal a strong impact of the general level of education, i.e. regional average schooling years are heavily influenced by national developments. This relationship, however, varies over time and resembles the explorative study regarding the interregional distribution of human capital in Austria: It becomes stronger until the 1990s and then weaker again. This means that the impact of region-specific characteristics has increased since where, in particular, the presence of low technology manufacturing displays negative effects while high technology manufacturing as well as market services display positive effects.

The second part of the explanatory study features panel regressions where the dependent variable equals growth of schooling years. The results confirm a convergence of human capital endowments. Furthermore, low and medium-low technology manufacturing industries as well as less knowledge-intensive services are identified as having negative impacts on schooling growth. While knowledge-intensive services display a positive impact on growth when controlling for initial schooling levels, no such effect can be detected for high and medium-high technology manufacturing industries. This result resembles SARDADVAR \& REINER (2015), who find no positive effect of knowledge-intensive industries on regional skill endowments even though the respective variables' definitions are different from the present study. In contrast, evidence for positive impacts of agglomerations and universities exist. Furthermore, while the spatial distribution of human capital displays positive neighbourhood effects, its development shows no such influence. However, relatively little is known about spatial dependencies regarding regional economic development within Austria, and more research is needed.

To summarise, the results show that human capital growth is no self-enforcing process. Furthermore, despite the obvious relation to the level of technology in manufacturing, there is no evidence of a causal relationship. Considering the growing importance of technology and skills for modern economies, this result may seem surprising and perhaps even disappointing. On the other hand, the impact of knowledge-intensive services is much stronger. Considering the strong role of manufacturing industries for Austrian production as well as exports in connection with the government's aim to increase Austria's human capital endowments, this result deserves further investigations. 


\section{References}

Abel J.R., Deitz R. (2012), Do Colleges and Universities Increase their Region's Human Capital? In: Journal of Economic Geography, 12, 3, pp. 667-691.

Abel J.R., Dey I., Gabe T.M. (2012), Productivity and the Density of Human Capital. In: Journal of Regional Science, 52, 4, pp. 562-586.

Abreu M., FagGian A., McCann P. (2015), Migration and Inter-industry Mobility of UK Graduates. In: Journal of Economic Geography, 15, 2, pp. 353-385.

Aiginger K., Falk R., Reinstaller A. (2009), Evaluation of Government Funding in RTDI from a Systems Perspective in Austria - synthesis report. Vienna, WIFO.

Allen M.M.C. (2006), The Varieties of Capitalism Paradigm: Explaining Germany's Comparative Advantage? Hampshire and New York, Palgrave Macmillan.

Berry C.R., Glaeser E.L. (2005), The Divergence of Human Capital Levels across Cities. In: Papers in Regional Science, 84, 3, pp. 407-444.

Combes P.-P., Duranton G., Gobillon L. (2007), Spatial Wage Disparities: Sorting Matters! In: Journal of Urban Economics, 63, 2, pp. 723-742.

CULPEPPER P.D. (2007), Small States and Skill Specificity - Austria, Switzerland, and Interemployer Cleavages in Coordinated Capitalism. In: Comparative Political Studies, 40, 6, pp. 611-637.

Edzes A., Hamersma M., Venhorst V., van DiJk J. (2015), Labour Market Performance and School Careers of Low Educated Graduates. In: Letters in Spatial and Resource Sciences, 8, 3, pp. 267-289.

EUROPEAN Commission (ed.) (2015), Innovation Union Scoreboard 2015. - http:/lec.europa.eu/ growth/industry/innovation/facts-figures/scoreboards/, accessed 14-October-2015.

FAGgian A., FrankLIN R.S. (2014), Human Capital Redistribution in the USA: The Migration of the College-bound. In: Spatial Economic Analysis, 9, 4, pp. 376-395.

FASSMANN H. (2002), Räumliche Disparitäten im österreichischen Schulsystem [Spatial disparities in the Austrian educational system]. Wien, Geschäftsstelle der Österreichischen Raumordnungskonferenz (ÖROK).

Fersterer J., Pischke J.S., Winter-Ebmer R. (2008), Returns to Apprenticeship Training in Austria: Evidence from Failed Firms. In: The Scandinavian Journal of Economics, 110, 4, pp. $733-753$.

Florida R., (2002), The Rise of the Creative Class and how it's Transforming Work, Leisure and Everyday Life. New York, Basic Books.

Florida R., Mellander C., Stolarick K. (2008), Inside the Black Box of Regional Development. In: Journal of Economic Geography, 8, 5, pp. 615-649.

GANong P., ShoAg D. (2012), Why has Regional Convergence in the US Stopped? (= HKS Faculty ResearchWorking Paper Series RWP12-028). Harvard, John F. Kennedy School of Government

GoodchILD M.F. (1986), Spatial autocorrelation (= Catmog, 47). Norwich, Geo Books.

Hall P.A., Soskice D. (2001), Varieties of Capitalism: The Institutional Foundations of Comparative Advantage. New York, Oxford University Press.

JANGER J. (2013), Strukturwandel als Indikator für die Qualifikationsnachfrage der Wirtschaft [Structural change as an indicator for the economy's demand for qualification]. In: WIFO Monatsberichte, 2, pp. 135-147.

Krugman P. (1991), Geography and Trade. Reprint 1992. Leuven - Cambridge (MA) - London, Leuven University Press, MIT Press.

López-Rodríguez J., Faî̃Na J.A., López-Rodríguez J. (2007), Human Capital Accumulation and Geography: Empirical Evidence from the European Union. In: Regional Studies, 41, 2, pp. 217-234. 
Lucas R.E. Jr (1988), On the Mechanics of Economic Development. In: Journal of Monetary Economics, 22, 1, pp. 3-42.

Mameli F., Faggian A., McCann P. (2014), Estimation of Local Employment Growth: Do Sectoral Aggregation and Industry Definition Matter? In: Regional Studies, 48, 11, pp. 1813-1828.

Mankiw N.G., Romer D., WeIL D.N. (1992), A Contribution to the Empirics of Economic Growth. In: Quarterly Journal of Economics, 107, 2, pp. 407-437.

Marshall A. (1890), Principles of Economics. Reprint 1938. London, Macmillan.

MöLler J. (2012), Methoden der empirischen Regionalanalyse [Methods of empirical regional analysis]. In: BRÖCKER J., FrITSCH M. (eds.), Ökonomische Geographie, pp. 7-36. Munich, Vahlen.

Palme G. (1995), Struktur und Entwicklung österreichischer Wirtschaftsregionen [Structure and development of Austrian economic regions]. In: Mitteilungen der Österreichischen Geographischen Gesellschaft, 137, pp. 393-416.

Pechar H. (2007), Der offene Hochschulzugang in Österreich [The open university access in Austria]. In: Badelt C., Wegscheider W., Wulz H. (eds.), Hochschulzugang in Österreich, pp. 21-81. Graz, Leykam.

Prager J.C., Thisse J.F. (2012), Economic Geography and the Unequal Development of Regions. Abingdon - New York, Routledge.

Ratтsø J., Stокке H. (2013), Regional Convergence and Education: Investigation of Distribution Dynamics. In: Urban Studies, 51, 8, pp. 1672-1685.

ReInER C. (2012), Play it again, Sam: Die Renaissance der Industriepolitik in der Großen Rezession [Play it again, Sam: The renaissance of industrial policy in the big recession]. In: Wirtschaft und Gesellschaft, 38, 1, pp. 15-56.

Republic of Austria (ed,) (2011), Der Weg zum Innovation Leader [The path to innovation leader]. Wien, Bundeskanzleramt.

SARDADVAR S. (2016), Vertiefen sich die räumlichen Wohlstandsgefälle innerhalb der Europäischen Union? [Are spatial welfare gradients increasing within the European Union?]. In: Wirtschaft und Gesellschaft, 42, 2, pp. 281-302.

SARdadvar S., Reiner C. (2015), The Long-run Distribution of Human Capital Endowments across Regions and its Impact on Employment: Evidence from Austria. In: Empirica. Journal of European Economics DOI: 10.1007/s10663-015-9311-5.

Schwabe M. (2006), Regionale Muster der Verteilung des Humankapitals in Österreich [Regional patterns of human capital dispersion in Austria]. In: Statistische Nachrichten, 9, pp. 797-807.

Shapiro J.M. (2006), Smart Cities: Quality of Life, Productivity, and the Growth Effects of Human Capital. In: Review of Economics and Statistics, 88, 2, pp. 324-335.

Soskice D. (1994), Reconciling Markets and Institutions: The German Apprenticeship System. In: Lynch L. (ed.), Training and the Private Sector: International Comparisons, pp. 25-60. Chicago, University of Chicago Press.

Südekum J. (2008), Convergence of the Skill Composition across German regions. In: Regional Science and Urban Economics, 38, 2, pp. 148-159.

\section{Appendix: List of districts}

The following list includes the 99 districts and statutory cities considered in this study, sorted by their superior federal states. The respective capital cities are marked by $*$, districts considered as suburban regions are marked by $* *$, districts which bordered member states of the Council for Mutual Economic Assistance are marked by ***. 
- Burgenland: Eisenstadt (Stadt)*; Rust (Stadt); Eisenstadt-Umgebung***; Güssing***; Jennersdorf***; Mattersburg***; Neusiedl am See***; Oberpullendorf***; Oberwart***

- Carinthia: Klagenfurt (Stadt)*; Villach (Stadt); Hermagor; Klagenfurt-Land**; Sankt Veit an der Glan; Spittal an der Drau; Villach-Land; Völkermarkt; Wolfsberg; Feldkirchen

- Lower Austria: Krems an der Donau (Stadt); Sankt Pölten (Stadt)*; Waidhofen an der Ybbs (Stadt); Wiener Neustadt (Stadt); Amstetten; Baden; Bruck an der Leitha***; Gänserndorf***; Gmünd***; Hollabrunn***; Horn***; Korneuburg; Krems (Land); Lilienfeld; Melk; Mistelbach***; Mödling**; Neunkirchen; Sankt Pölten (Land); Scheibbs; Tulln; Waidhofen an der Thaya***; Wiener Neustadt (Land); Wien-Umgebung**; Zwettl

- Upper Austria: Linz (Stadt)*; Steyr (Stadt); Wels (Stadt); Braunau am Inn; Eferding; Freistadt***; Gmunden; Grieskirchen; Kirchdorf an der Krems; Linz-Land**; Perg; Ried im Innkreis; Rohrbach***; Schärding; Steyr-Land; Urfahr-Umgebung*****; Vöcklabruck; Wels-Land

- Salzburg: Salzburg (Stadt)*; Hallein; Salzburg-Umgebung**; Sankt Johann im Pongau; Tamsweg; Zell am See

- Styria: Graz (Stadt)*; Bruck an der Mur; Deutschlandsberg; Feldbach; Fürstenfeld; Graz-Umgebung**; Hartberg; Judenburg; Knittelfeld; Leibnitz; Leoben; Liezen; Mürzzuschlag; Murau; Radkersburg; Voitsberg; Weiz

- Tyrol: Innsbruck-Stadt*; Imst; Innsbruck-Land**; Kitzbühel; Kufstein; Landeck; Lienz; Reutte; Schwaz

- Vorarlberg: Bludenz; Bregenz*; Dornbirn; Feldkirch

- Vienna: Wien 